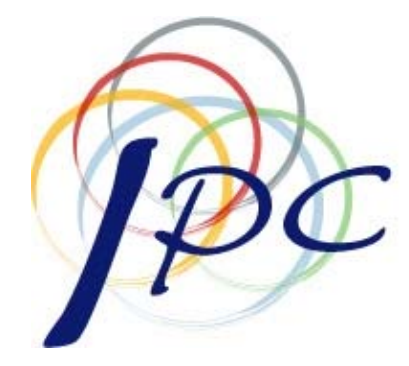

International Policy Center

Gerald R. Ford School of Public Policy University of Michigan

IPC Working Paper Series Number 6

\begin{abstract}
Entrepreneurship and the Evolution of Income Distributions in Poland and Russia
\end{abstract}

Daniel Berkowitz and John E. Jackson

Revised November 2005 


\title{
Entrepreneurship and the Evolution of
}

\section{Income Distributions in Poland and Russia}

\author{
Daniel Berkowitz \\ Department of Economics \\ University of Pittsburgh \\ WWPH 4711 \\ Pittsburgh, PA 15260
}

\author{
John E. Jackson* \\ Department of Political Science \\ University of Michigan \\ 7766 Haven Hall \\ Ann Arbor, MI 48109
}

\begin{abstract}
*Corresponding Author
We thank Erik Berglof and Ariel Pakes for suggesting this topic. We also thank Yuri Andrienko for help with the Russian data and Jacek Klich, Krystyna Poznańska and Jósef Chmiel for help with the Polish economic data and The Institute for Social Studies at the University of Warsaw for sharing the PGSS data. We also thank John Bonin (our editor) and an anonymous referee for useful comments.
\end{abstract}




\begin{abstract}
Differences in the evolution of income distribution in Poland and Russia in the postsocialist era are striking: for example, in Poland, the gini coefficient on earnings went from 0.28 to 0.33 between 1988 and 1998 while in Russia it went from 0.27 to 0.47 (UNICEF, 2001). We argue that these differences can be accounted for, in part, by the different patterns of entry of de novo firms and of spin-offs from privatized state companies (for herein denoted small enterprises). We use regional differences in early privatization as instruments to estimate the effect of small enterprises on income distribution. Early privatization is a plausible source of variation in small enterprises because it can either foster or deter entry and development via its impact on the regulatory environment. Using this identification strategy, we find, most notably, that a one standard deviation increase in the share of the workforce in small enterprises increases the share of income earned by the lowest 40-percent of the population by 1.4 percentage points in the Polish regions between 1993 and 1998 and by 1.25 percentage points in the Russian regions between 1995 and 2001. Our results suggest that early privatization in Poland was more successful in supporting an equitable income distribution via small enterprise development than in Russia.
\end{abstract}

\title{
JEL Codes: $\quad$ D3, O87, P2
}




\section{Entrepreneurship and the Evolution of Income Distributions in Poland and Russia}

The increased income inequality observed in the transitional economies in Central and Eastern Europe and the former Soviet Union is a topic of considerable concern and examination of its possible causes. (See UNICEF, 2001, and World Bank, 2000.) The more successful transitional economies in Central and Eastern Europe experienced relatively modest increases in inequality, generally on the order of increases of 0.05 in the country's gini index between 1987 89 and 1997-99, and are still about or below the OECD average of 0.31. In contrast, the CIS countries, which are generally seen as having less successful transitions, have average gini increases of 0.17 in that same period and all except Belarus have gini coefficients well above the OECD average. (See UNICEF, 2001.) These observations raise the intriguing question of whether the relatively rapid and successful creation of a capitalist market economy has salutary effects on income distribution. This paper explores this question and contributes to the debate on why inequality has increased by examining the relationship between the rates of creation and growth of small private enterprises and changes in the income share of the bottom two quintiles within regions in Poland and Russia.

The Russian and Poland illustrate two quite different transition experiences. Poland's real GDP increased every year beginning with the third year of the transition and exceeded its pretransition level by year six. According to UNICEF data the gini coefficient measuring income inequality increased from 0.28 to 0.33 between $1987-89$ and 1997-99. ${ }^{1}$ Russia, on the other hand, experienced a major contraction during 1991-98 and real GDP in 2003 is still below the pre-transition level, despite significant growth since 1998. Accompanying this income fall has been an enormous increase in inequality. According to the UNICEF data the gini coefficient for income increased from 0.27 to 0.47 between $1987-89$ and 1997-99. ${ }^{2}$ This paper takes these contrasting experiences as an opportunity to test propositions about how the entry and growth of new small firms is related to changes in the distribution of income. If we find comparable relationships in these two vastly different economies it increases the credibility of our 
proposition. We then conclude the paper with some observations about why the Russian and Polish experiences and outcomes are so different.

The next section presents arguments for why increased small enterprise growth is likely to flatten the income distribution and benefit those in the lower quintiles. Section 3 describes the regional variations in income distributions and the size of the small enterprise sector in Poland while section 4 does the same for Russia. The following two sections discuss the estimation methods, which recognize the endogeneity of new firm creation and growth, and the statistical results. The final section presents some concluding thoughts comparing the Polish and Russian experiences and suggesting why Poland did not have the large increase in inequality seen in Russia.

\section{New Firm Entry and Changes in Income Distribution}

Small enterprises entered as de novos, as spin-offs from state enterprises, or as the result of small scale privatization of state firms. In either case, there are several reasons to expect higher rates of small enterprise creation to promote a more equitable income distribution. First, these new small enterprises were virtually the sole source of job creation in the transitional economies, offsetting the layoffs produced by hard budget constraints, privatization and restructuring among the state and former state firms. (See Bilsen and Konings, 1998, for evidence from Romania, Bulgaria and Hungary; Jackson, Klich and Poznańska, 2005 for evidence from Poland; and Jurajda and Terrell, 2001, for evidence from the Czech Republic and Estonia.) The wages earned in these jobs will boost incomes at the lower end of the income distribution as they will be greater than any likely unemployment benefits.

A second way that new small enterprises contribute to a higher and a more equitable income distribution is through their contribution to aggregate productivity. There is empirical evidence that these new firms have higher productivity than the firms they are replacing, following the Schumpeterian idea of creative destruction. Using a detailed sample of 24 countries, Bartelsman, Haltiwanger and Scarpetta (2004) document that in the post socialist 
transition economies new firms are primarily small and the firms they are replacing are large state enterprises; they also show that productivity gains from entry and exit are most pronounced in the transition economies (see also Klapper, Laeven and Rajan, 2004). DeLoecker and Konings (2006) develop a comparison of new and old manufacturing firms in Slovenia based on estimates of total factor productivity. One of their findings is that the net entry of de novo private firms is an important determinant of growth in total factor productivity. Jackson, Klich and Poznańska (2005), using longitudinal data on cohorts of new and old enterprises, find several relationships that are consistent with the DeLoecker and Konings results. They do not have measures of total factor productivity but examine sales per worker as a substitute. They find that within cohorts of new firms both survival and growth are strongly related to average sales per worker, indicating that over time the most productive firms are employing a larger share of the workforce. They also show that the wage growth among surviving firms in a cohort is strongly related to sales per worker and to the firms' sales growth. Lastly, their analysis indicates that wage growth is more closely tied to productivity growth in the surviving small enterprises than it is among the state and former state owned firms. In the short-run it is impossible to say how this Darwinian process will affect regional incomes as that will be a function of the aggregate demand for and supply of labor, which will be related to more factors than just the number and growth of new firms, such as the unemployment rate. (For discussions of how wages might relate to unemployment see Jackson, 2003 and Tichit, 2006.) In the longer run, however, with a competitive labor market the equilibrium wage will reflect this higher level of productivity among the surviving new firms.

Lastly, a high rate of entry and survival of new firms increases the competitiveness of product and labor markets, eventually eliminating the monopoly rents that accrue in concentrated markets (McMillan, 1995). Johnson, McMillan and Woodruff (2002) argue that in the first years of transition small de novo and spin-off firms in Poland and Russia (and in many other postsocialist economies) entered sectors, such as consumer goods, light manufacturing, trade and services that had been dominated by large state enterprises under socialism. The inefficiencies of 
the state enterprises in these sectors created tremendous profit opportunities for initial entrants. Over time, the continued entry of these firms reduced these profits. Johnson, et. al. (2002) show that in Poland by 1995 these rents fell as competition increased. This was not so true in Russia, however, as the slow development of market supporting institutions and lower rates of firm entry led to the persistence of initially high profit rates (see McMillan and Woodruff, 2002). ${ }^{3}$ Also, Frye and Shleifer (1997) present evidence that in 1996 small firms in Warsaw were operating in a more competitive market than their counterparts in Moscow. The small enterprise sector then provides employment through its job creation and also boosts productivity. If the entry of small enterprises is accompanied by the reduction of monopoly rents because of increased competition in a broad range of industries and if distortionary regulations are gradually removed, then in the long run we would expect that payments to labor would more accurately reflect the marginal productivity of labor and small enterprise entry is likely to produce higher wages.

\section{Income Distribution and New Firm Creation in Poland}

Estimates of regional income distributions and of the size of the small enterprise sector in Poland come from specialized data collections. The Polish Central Statistical Office does not disseminate publicly data on the regional distribution of income, necessitating a second best strategy. The Institute for Social Studies at the University of Warsaw has conducted the Polish General Polish Social Survey since 1992 (Cichomski and Morawski. 2002). This survey interviewed a nationally representative random sample of about 1600 households in 1992, 1993, 1994 and of about 2300 households in 1997 and $1999 .{ }^{4}$ One of the questions asked for total monthly family income. The 1992, 1993 and 1994 samples are pooled and family incomes in 1993 and 1994 adjusted to 1992 price levels using the consumer price index. This set of respondents is referred to as the 1993 sample. Similarly the 1997 and 1999 surveys are pooled and 1999 incomes adjusted to 1997 levels. This sample is referred to as the 1998 sample. Each is disaggregated by region (voivodship), of which there are forty-nine. 
Measures of income distribution, or inequality, are computed for each region based on the respondents residing in that region. Table 1 provides descriptive statistics for the means and ranges among voivodships. (The Warsaw region is omitted from these statistics for reasons we discuss subsequently.) The average income share of both the first and second quintile is essentially flat during the 1993 to 1998 period, being about twenty-two percent in both surveys. The average shares for the first quintile are also quite stable, at eight percent. The standard deviation of regional shares of the first two quintiles increased between 1993 and 1998 while the range decreased, with the lowest regional share increasing by almost a percent and a half. In the first quintile both the standard deviation and the range of income shares increased between 1993 and 1998, with the maximum share increasing by over four percent. The stability in mean income shares between 1993 and 1998 disguises substantial variation in the changes in shares. The correlations between 1993 and 1998 shares across the regions are 0.2 for the first quintile and -0.21 for the first and second quintile. In terms of changes in shares, the mean changes are only $0.1 \%$ and $0.2 \%$ for the first and second quintiles respectively, but there is a very large range, going from $-9.8 \%$ to $+12.2 \%$ for the first and second quintiles combined. These statistics indicate considerable regional variations in the change in shares, and the question is whether these changes are related to the size and growth of the small enterprise sector.

(Table 1 About Here.)

The lower half of Table 1 shows the regional sample sizes on which these distributional statistics are calculated. The median sample size is eighty one for the 1993 sample and 73.5 for the 1998 sample. The smallest sample sizes are twenty-two and twenty-one respectively. There are two important considerations in evaluating these statistics. One, obviously, is the accuracy of the sampled distributional statistics relative to the population values in the regions, which is a function of sample size. In our subsequent statistical analysis we weight by these sample sizes in order to adjust for these sampling errors. Combining regions with smaller sample sizes presents two problems. One is that it would reduce the degrees of freedom in our analysis relating 
changes in regional income shares to the de novo sector. A second is that the regions with small samples are not contiguous, making any aggregation very arbitrary. For these reasons we think our strategy of keeping the regions intact and weighting by sample size is the best alternative.

The source of error that is potentially more worrisome is that the PGSS study is a representative sample for the nation and for broad regions but not a representative sample of each voivodship. The potential problem created by this circumstance is that our income distribution measures for each region may only reflect the distribution among a non-representative subset of the population. There is no way to address this problem with the current data, as these are the only data available for assessing income distributions on a regional level, so we proceed with them. We can offer one assessment of the sample by comparing the sample sizes in each voivodship with its population. The greater the proportional differences the less likely the voivodship is adequately represented in the PGSS sample. The simple correlation of the sample size and population variables is 0.93 . The ratio of the regional sample size to the voivodship population divided by ten is 1.19 with a standard deviation of 0.37 and the log of this ratio had a mean of 0.13 and a standard deviation of 0.32 . We correlated this ratio and its log with a series of variables describing each voivodship, such as its population, average salary, rate of de novo firm and job creation, etc. None of the individual correlations was close to being statistically significant (the lowest $\mathrm{p}$ level is 0.25 ) and a multiple regression including all the variables had an adjusted r-squared of -0.13 and an F-statistic of 0.51 with eleven and thirty-six degrees of freedom, which implies a p level of 0.88 . Based on these comparisons we believe there is a high degree of correspondence between the regional sample sizes and populations and see no systematic variation in the deviations from this ratio. Thus, with the corrections for sampling error we should get good estimates of the relationship between small enterprise creation and income inequality and have reliable estimates of their uncertainty.

Measuring the size and growth of the small enterprise sector in transitional economies is a daunting task. In Poland, however, we have access to a unique dataset developed by the 
Economics and Statistics Research Office of the Polish Central Statistical Office (GUS) that enables us to focus on small de novos and spin-offs versus small privatized firms. The GUS created longitudinal data tracking individual firms from annual reports filed by individual enterprises that measure the entry, survival and growth of new firms for the period 1990 through 1997. (See Jackson, Klich, and Poznańska, 1999 and 2005.) The firms' filings are linked to follow the survival and employment growth of small firms that existed in 1990 and the entry, survival and growth of new firms that entered after 1990. From these data we calculate the number of firms in each region in 1997 that were small in 1990 or had entered since then and their total employment. These counts of employment and firms are denominated by the size of the workforce and by population, respectively. The density of these firms per capita and their employment share in 1997 and the change in their employment share from 1993 to 1997 are our measure of the size of the small enterprise sector in each region. Table 2 shows the summary statistics for these variables.

(Table 2 About Here.)

One limitation of these data is that the GUS did not require reporting by firms with five or fewer employees. Consequently these data omit information about the very smallest sector. Another agency collects data on firm registrations by region. Their data for the firms with five or fewer employees grossly overstate the amount of de novo activity, for a number of reasons, so are not reliable and are not used in this study. ${ }^{5}$ Jackson and colleagues have done some statistical comparisons with the GUS and registry data for firms of all sizes (Jackson, Klich and Poznańska, Appendix A, 2005). They conclude there is no evidence of systematic regional differences or biases between the two data sources and that the GUS data are a more reliable estimate of local de novo and spin-off activity. Thus, we feel comfortable using these data despite the omissions.

The GUS data, despite the omission of very small firms, present several distinct advantages over the usual data that measure the size of the small and medium enterprise (SME) sector or that track the registration of new firms. Most importantly, these data track both growth 
and exit, producing a more reliable estimate of de novos and spin-offs. We have already mentioned that the registry data do not measure exits, leading to an overstatement of the size of the small enterprise sector. The conventional data on SME's present the opposite problem. Over time the most successful new firms will no longer by classified as a small or medium sized enterprise and will be omitted from the SME data. The more successful a region is in the entry and growth of a small enterprise sector the more likely the SME data will be to understate its size and importance.

Thirdly, most data on the size of the private sector, whether limited to SME's or not, do not separate de novo and spin-off firms from small privatized firms. The latter may function very differently than the former in terms of creating the amount of competition and growth needed for a healthy market economy. In many cases limiting the measure to SME's overcomes the most serious aspects of this bias, but at the expense of missing the most successful new firms. On balance, we think the GUS data are the best available measures of the size and growth of the small de novo and spin-off firms in Poland. We are confident these are new firms and that we have measured the number and employment of the most successful of these firms on a regional basis.

\section{Income Distribution and Small Enterprises in Russia}

This section draws upon official Russian sources summarizing income distribution and small enterprise formation. We use published regional data supplied by the official Russian statistical agency (Goskomstat Rossii, 1996, 2001, 2002). These contain representative regional surveys of household income, regional registries of small enterprises, and data on the number of employees and sales in these new enterprises. Regional income distribution is reported in 1995, 2000 and 2001 and the methodology does not change over time. Russia contains 89 regions; the 1995 national survey covers 75 of the regions, and the 2001 survey covers 77 . We match data

from the national sample with our regional data set, which includes early privatization data and 
other regional covariates, and obtain a sub-sample of 66 regions in 1995 and 2001 (Moscow and St. Petersburg are excluded for reasons we discuss in the next section).

Table 3 reports the share of income held by the bottom 20-percent and bottom 40-percent of the regional income distribution in 1995 and 2001 and illustrates several patterns. First, between 1995 and 2001 income distribution within Russian regions becomes slightly more inequitable: using either the national mean (based on the fully reported data set) or regional mean (based on the sub-sample). Between 1995 and 2001 households in the bottom 40-percent of the income distribution on average lost 1-percentage point of their share of overall income; and, households in the bottom 20-percent lost roughly a half percentage point. Russian income distribution dynamics during 1995-2001 are very different than the relatively flat changes in income distribution in Poland during 1993-98. Second, in Russia, the more dynamic changes in mean income shares between 1995 and 2001 disguise less variation across regions. For example, the correlation between 1995 and 2001 income shares are 0.46 and 0.45 for the first quintile and first and second quintiles combined. And, while the changes in shares are also relatively larger $(-0.5 \%$ and $-1.0 \%$ for the first quintile and the first and second quintiles combined), the range across regions is relatively smaller (from $-6.5 \%$ to $5.2 \%$ for the first and second quintiles combined). Nevertheless, there is more than enough variation across the regions over time for us to be able identify reasons for the change in distributions. Finally, it is also clear that income distribution is more inequitable in Russia: during 1993 and 1998, the bottom 40-percent (20-percent) in Poland receives roughly $21.65 \%(7.75 \%)$ of the income, while in Russia, during 1995 and 2001, this group receives $19.6 \%(7.35 \%)$.

\section{(Table 3 About Here.)}

We use small enterprise employment as a share of the regional workforce and the registry of small enterprises per 1000 population as measures of small enterprise development. These legally registered small enterprises include spin-offs from state enterprise and start-ups as well as privatized small former state enterprises. Thus, we are not able to separate small de novos and 
spin-offs from the small privatized firms as we did in the Polish GUS data set. Before 1996, these small enterprises were defined by employment ceilings: over the course of a year on average a small enterprise could hire no more than 200 workers; and employment ceilings varied across branches, for example, the ceiling was 100 in scientific services and 15 in retail trade. However, as of 1996, small enterprises are defined by both ownership structure and employment. Regarding ownership, any enterprise, no matter how small, is not legally defined as small if it has an outside owner (a large company, a charitable organization, social organization or religious organization) that owns at least $25 \%$ of the initial enterprise capital. And, regarding employment ceilings, these have also changed and generally become smaller, for example, the highest ceiling is now 100 and applies to industry, construction and transport; and, the retail trade ceiling is elevated to 30 employees on average per year. Because the definition of a Russian and Polish small enterprise is very different, our small enterprise data cannot be used to compare small enterprise levels in these two countries.

Table 4 reports data on the evolution of small enterprises for pairs of years in which the definitions are comparable and for which data are available. Remarkably, the number of small enterprises per capita and the share of the labor force employed in small enterprises decreases over time. There is an increase in employment shares in only one region in our sub-sample (Nizhni Novgorod). Moscow and St. Petersburg appear to be outliers because the increase in labor force employed in small enterprises during 1995-2001 in these cities is roughly three and four standard deviations about the median region in our sub-sample, and roughly one and two standard deviations above Nizhny Novgorod. Thus, even though we are using somewhat different definitions of start-up and de novo activity, it is clear from the sub-sample reported in Tables 2 and 4, or even if we include Moscow and St. Petersburg in the sample, that small enterprise development is much more dynamic over time in Poland than in Russia.

(Table 4 About Here.)

\section{Estimations Relating New and Small Enterprises and Income Distribution}


In this section we discuss estimation of the influence of small enterprise development on income distribution in Poland 1998 and Russia 2001, which begins with the following equation:

$$
\Delta D I S T_{t}=\alpha+\beta S M E N T+\delta X+\delta D I S T_{t-1}+\varepsilon_{t}
$$

where $\triangle D I S T_{t}, D I S T_{t-1}, S M E N T$, and $X$ denote the change in income distribution (measured as the share of income going to the bottom 40-percent of the distribution in a region) between period $t$ and $\mathrm{t}-1$, the income distribution in period $\mathrm{t}-1$, small enterprise development and a vector of regional covariates. In $X$ we include $\log$ population to capture the extent of the market and education as both have been identified as important determinants of income distribution and small enterprise development. The primary measure for small enterprise development, SMENT, is the employment share of this sector in 1997 in Poland and in 2001 in Russia. SMENT is also measured by the number of de novo private firms denominated by population divided by one thousand and then by the change in de novo private employment share from 1993 to 1997 for Poland and for 1995 to 2001 for Russia.

Estimation of eq. 1 is complicated by the possibility of reverse causality. Gabszewicz and Thisse (1980) and Shaked and Sutton (1982) show through formal models that the entry of new firms in markets characterized by monopolistic competition is related to the distribution of income. There is also a set of empirical studies arguing that more equitable income distributions are associated with higher rates of economic growth. For a summary of this research see Aghion, Caroli and Garcia-Peñalosa (1999) and Forbes (2000) for a contrary view. Keane and Prassad (2002) report a strong negative correlation between growth and inequality for fourteen transition countries over the first eight years of the transition. If growth in these countries is strongly related to the growth of the de novo sector, as we believe it is, then our measures of small enterprise development will be endogenous in eq. 1.

To overcome the estimation problems created by this endogeneity we develop a set of instruments for SMENT that should provide consistent estimates for the relationship between new 
enterprise development and changes in income equality. We use early privatization and initial conditions as our instruments. Because of differences in data availability and in their approaches to reforms the precise variables differ in each country. For Russia the two instruments are the large and small scale privatizations, defined as the number of privatized firms in each category per 1000 population (source: Goskomstat, 1994). ${ }^{6}$. In Poland only data on large scale privatization, defined as the proportion of the 1993 workforce employed in firms privatized to that point, is available. Additional relevant initial condition variables are the proportion of the 1990 non-farm workforce employed in state-owned enterprises and the proportion of the workforce employed in private enterprises with fewer than one hundred employees. ${ }^{7}$

The first requirement for our instruments is that they be directly related to the size of the de novo enterprise sector. This assumption is inspired by McMillan (1995), who argues that early privatization affects the emergence of a regulatory environment that enhances the entry and development of small enterprises. It is expected that privatization, if done properly, weakens the political connections of the controllers of formerly state owned enterprises. In this case governments, both national and local, would not have an incentive to use their tax and regulatory policy to protect state owned enterprises against entering small enterprises. Further, governments can expand their tax base and enhance the standard of living by developing a pro-small business regulatory environment. If privatization fails to eliminate these political connections then we have the same conditions that exist with a large concentration of state enterprises where governments will have an incentive to protect the large enterprises. Berkowitz and Holland (2001) find strong positive relationships between new firm registrations and federal and regional privatization in Russia, but small negative relationships for local privatization.

The greater the degree of capture of government agencies by the privatized firms and the smaller the separation of these firms from the government the weaker should be the relationship between privatization and new firm entry. Poland and Russia have quite different privatization experiences. Poland proceeded very slowly with large scale privatization while Russia privatized 
very rapidly. Several papers argue that early Russian privatization led to a corrupt regulatory environment that persisted through at least the mid 1990s while early Polish privatization had the opposite effect. (See Alexeev, 1999; Berkowitz and Li, 2000; Black, Kraakman and Tarassova, 2000; Frye and Shleifer, 1997; Hellman, 1998; and Shleifer and Vishny, 1993.) A number of estimates of corruption indicate far less corruption in Poland than in Russia (Johnson, et. al., 2002; Hellman, Jones and Kaufman, 2000; Karatnycky, et. al., 2001; Transparency International, 1996) and less governmental capture (Hellman, et. al., 2000). These differences should produce stronger associations between large scale privatization and new firm growth in Poland than in Russia.

Initial conditions are important factors in the development of the Polish de novo private sector. Poland had a nascent small private sector and a varied mix of state-owned, collective and large domestic and foreign enterprises before the transition began. The concentration of these enterprises varied substantially by region. Given the importance of agglomeration, learning, and political effects the presence of a significant number of small private enterprises at the beginning of the transition gives a region a substantial advantage in expanding its de novo sector as the transition proceeds. The presence of state-owned enterprises at the beginning of the transition is expected to depress the entrepreneurial process and therefore the growth and ultimately the size of the de novo sector. These enterprises pay higher wages, thus raising the labor costs and reducing its supply for new enterprises, which will restrict their growth. Even within the more benign Polish environment these firms are likely to be able to exert undue influence on a range of institutions from financial organizations to governments for preferential treatment and various subsidies, which again creates an unfavorable climate for enterprise creation. Finally, there is empirical evidence from the U. S. and Poland that individuals residing in regions dominated by large organizations, which dominate the state-owned sector, independent of the size of their own employer, and employees in large organizations express less support for entrepreneurs and are less likely to say they would undertake entrepreneurial activity. (Jackson and Rodkey, 1994 and 
Jackson and Marcinkowski, 1999.) All three factors lead us to expect a negative relationship between a region's density of state-owned enterprises and the development of its de novo sector. These initial conditions will be relatively unimportant in explaining the development of the de novo sector in Russia as there was virtually no small private sector and all employment was in state firms at the beginning of the transition.

A second assumption in our choice of instruments is that they are not systematically related to the change in the income share of the bottom two quintiles after we control for new firm entry, lagged income shares, education and population. In other words, their effect on income shares is only through their relationship with new firm creation and growth. In order to empirically validate this identifying assumption we take two steps. First in the estimating equation we control for the influence of initial income distribution. Initial conditions and early privatization are measured prior to our measure of initial income shares so that if these variables directly affect inequality their strongest effects should be on this variable and not on the subsequent change in income. Second, we validate our exclusion restrictions by employing over-identification tests. (See Hansen, 1982, and Baum, Schaffer and Stillman, 2003.) These tests examine whether the identifying variables are individually or jointly correlated to the changes in income distribution conditional on firm entry and the other covariates in equation (1). If we do not reject the null hypothesis of no correlation it provides some statistical confidence in our assumption. ${ }^{8}$

Based on these propositions the first stage regression used to identify the impact of

\section{SMENT on $\triangle D I S T$ is}

$$
S M E N T=\alpha_{1}+\beta_{1} P R I V+\beta_{3} C O N D_{0}+\delta_{1} X+\varepsilon_{1}
$$

where PRIV denotes the privatization during 1990-93 for Poland and small and large privatization in 1993 for Russa and $C O N D_{0}$, which applies only for Poland, is the 1990 employment in small private and in state-owned firms. ${ }^{9}$ We therefore use the variables in PRIV and in $\mathrm{COND}_{0}$ as over-identifying restrictions when we estimate (1) for either Poland or Russia. ${ }^{10}$ 
We make one adjustment to the data before estimating eqs. 1 and 2. The Warsaw region is dropped from the Polish sample and the Moscow and St. Petersburg regions are dropped from the Russian sample because they are extreme outliers whose inclusion exerts undue influence on the results. (The dfits statistics for Warsaw for each first stage estimation are about six times larger than both the next largest value and the conventional threshold for concluding the observation may be problematic.) Warsaw is the capital city with a very high proportion of government employees, whose wages are not determined by usual market forces but are more reflective of political interests. Warsaw also had a large de novo private sector by 1997 and dominated the rest of the country in the amount of foreign investment, accounting for about half of all employment in new foreign owned firms. Fig. 1 plots the proportion of the workforce in de novo private domestic and foreign firms for each region, ranked from highest to lowest. Warsaw has the largest proportion of both, but as Table 2 indicates there is still substantial regional variation in the size of the de novo sector.

(Figure 1 About Here.)

Moscow and St. Petersburg are outliers from the standpoint of new firm creation: Moscow is 4.6, 2.6, and 4.8 standard deviations above the mean and St. Petersburg is 4.5, 3.5, and 5.2 standard deviations about the mean for the 2001 small enterprise employment share, the 1995 to 2001 change in small enterprise employment share, and in 2001 enterprises per capita. (Standard regression diagnostics for the first stage regression equation confirm that these two cities have the ability to exert undue influence on our estimates.) Also, the extent of foreign activity in Moscow and St. Petersburg sets these two regions apart from than the rest of Russia. In 2001, they attracted 48-percent of foreign investment. Figure 2 plots the share of the regional workforce employed in foreign joint enterprises that are also small enterprises, ranked from highest to lowest. Moscow and St. Petersburg have the highest and second highest proportions. While we exclude them from the Russian analysis because of their potential to exert undue influence, if we in fact include Moscow and St. Petersburg our results are robust when we use small enterprise 
shares to measure new enterprises, while they are somewhat noisier when we use the small enterprises per capita or the change in employment shares. ${ }^{11}$

(Figure 2 About Here.)

\section{Empirical Results}

Tables 5 and 6 contain our empirical results for Poland and Russia, respectively. In panel A in both tables we report 2SLS estimates of equation (1); in panel B we report test statistics that check for the validity of our instruments; in panel $\mathrm{C}$ we report corresponding OLS estimates and panel D we report the first stage estimates of the influence of early privatization and initial conditions on small enterprises.

\section{(Tables 5 and 6 About Here.)}

Small enterprise development in 1997 in Poland, whether measured by employment share, enterprises per capita, or change in employment share has the expected positive impact on the change in income distribution between 1993 and 1998 and is always significant at the 5percent level. To gauge the quantitative significance (QS) of small enterprises, we compute the impact of a one standard deviation increase in small enterprise development on income distribution. Quantitative significance of small employment, the number of small enterprises, and the change in employment is $1.44,1.58$ and 1.72 percentage points, all of which are close to or above half a sample standard deviation of income going to the bottom 40-percent in 1998 (3.0 percentage points).

Panel B provides two sets of tests that check for the validity of excluding early privatization from the 2 SLS estimates in (1). First we provide t-statistics and associated p-values to test the null that each instrument can separately be excluded from the second stage. For example, the t-statistic for employment in private firms in 1990 divided by the workforce reported in the first regression column tests the null that this variable's coefficient is not statistically different from zero if only it is included in the second stage while using the identifying restriction that the other instruments are excluded. The remaining rows and columns 
repeat this process for each instrument and each model. Remarkably, in the nine cells for our three regression columns, the lowest p-value associated with these t-statistics is 0.45 . Second, we report the J-statistic which tests the null hypothesis that the three privatization instruments are not jointly correlated with the error term in the second stage estimates (see Hansen, 1982, or Baum et al, 2003). All the p-values are above 0.4 , so we again do not reject the null. Thus, the early privatization and initial condition variables appear to be valid instruments.

Panel C reports OLS point estimates of the impact of small enterprises on income distribution. In all three cases the 2SLS points estimate are higher which suggests that the 2SLS has corrected for some of the simultaneity bias.

Panel D reports the first stage OLS estimates of the impact of early privatization and employment in state enterprises on small enterprise development. The early privatizations, in each case, have strong positive and statistically significant coefficients and the concentration of state enterprises has a significant negative impact on subsequent small enterprise development. The F-statistic for excluded instruments tests the null that the early privatization measures and initial concentration of state enterprise can be jointly excluded from the first stage; and the partial $\mathrm{R}^{2}$ checks for the share of the variance explained by these instruments. Both statistics attest to the enormous strength of these instruments.

Turning to the results for Russia, Table 6, panel A shows that all three small enterprise variables have a positive and statistically significant impact on income distribution in 2001. The quantitative significances are $0.98,1.49$ and 2.30 percentage points for the employment share, number of firms and change in employment shares respectively, which are all substantial compared to the 2.2 percent standard deviation in regional income distribution. Again, as we saw in Poland, the entry of new firms and their employment is strongly and positively related to the increases in income share of the lower two quintiles.

The t-test statistics and J-test statistics in panel B provide validation for using early large and small privatization as instruments for employment share and number of firms in 2001 and 
change in employment share in the new small sector. The OLS estimates of the impact of these variables on income distribution in Panel $\mathrm{C}$ are positive and statistically significant and, as in the case of Poland, substantially lower than the corresponding 2SLS estimates. Panel D shows that in Russia, as in Poland, early privatization is always positively associated with subsequent small enterprise development. The early small privatization measures are statistically significant in all 3 models and the large scale privatization variable is significant in one model. The F-test for excluded instruments and the partial $\mathrm{R}^{2}$ values show that these instruments are strongest in the equation for employment share in 2001 and weaker for the other two measures.

In Table 7 we compute the indirect quantitative significance of early privatization on income distribution in the following two step fashion: first, we multiply a one-standard deviation change in one of the early privatization measures times its impact on small enterprise formation and obtain the quantitative significance of a particular form of early privatization on small enterprises; we then take this statistic and multiply it times that impact of small enterprises on subsequent income distribution. It is notable that regardless of whether we use employment, number of firms or change in employment as the measure of early small enterprise development in Poland, early privatization in 1990 is associated with a 0.6 to 0.7 percentage point increase while subsequent privatization during $1990-93$ is associated with about a 0.3 to 0.5 percentage point increase in the income shares of the bottom 40-percent of the distribution. Comparable increases in the employment in state enterprises in 1990 are associated with a 0.4 to 0.7 percentage point decrease in these income shares. This suggests that early small privatization is relatively more important for income distribution. And, it is also appears that the impact of early privatization on income distribution is much stronger in Poland than in Russia: the average impact of early privatization is 0.65 percentage points in Poland versus 0.22 percentage points in Russia This suggests that early privatization, via its impact on small enterprise development, has been a more powerful force for an equitable income distribution in Poland.

(Table 7 About Here.) 


\section{Conclusions}

The empirical results show a strong positive relationship between the size and the growth of the de novo sector and the income share of the bottom two quintiles of the distribution. In both Poland and Russia the average impact of a one standard deviation increase in any of our measures of new enterprise activity on the income share of this group is roughly $1.6 \%$. This consistent evidence from these two different countries lends credibility to our proposition relating new firm creation to the income distribution, as we suggested in the introduction.

These results take on added significance when considered alongside the Berkowitz and DeJong (2005) finding that a one standard deviation increase in the size of the small firm sector is associated with a one and a half percent increase in annual income growth during 1993-2000. We did a similar analysis for Poland where log of mean income in 1998 and 1993 are substituted for the income distribution variables in the equations reported in Table 5. Each measure of de novo firm activity is statistically significantly related to income growth with a one standard deviation increase associated with a one percent higher annual income growth rate. ${ }^{12}$ These results indicate that new firm creation is associated with a larger income pie and a larger slice of that pie for the lower quintiles, making the members of this group better off in both absolute and relative terms. These results also suggest that there is a positive association between per capita income and income distribution, and that small enterprises are an important reason for this association. Checking for the strength of this association is of interest since there is evidence that overall growth in Russia since 2001 has also been associated with some improvement in income distribution (see United Nations, table 15, 2005). This issue, however, requires additional data and sophisticated systems tests and is an area of future research.

The opening section notes the strikingly different changes in the Polish and Russian income distributions in the first decade of transition. Our results along with the descriptive data for the two countries allow us to offer some thoughts about why these two different outcomes occurred. A critical aspect of the differences in the two transitions is the rate and character of new private 
firm creation. Kornai (2000), for example, recognizes Poland as a transitional economy built on a high level of organic de novo firm creation and of spin-offs from old state firms. He contrasts this with Russia, among others, where the emphasis was on privatization, with much lower rates of firm creation. Our Polish and Russian data are not comparable as the former measures new firm creation and growth while the latter measures the size of the small enterprise sector, though most of this activity is likely to be new firms. What is evident in Table 2 is that the de novo sector in Poland by 1997 demonstrated robust growth. Employment in these firms more than doubled between 1993 and 1997 and the most successful regions, even excluding Warsaw, demonstrated a very dynamic de novo sector. Table 4 shows that in Russia, by contrast, the small enterprise sector actually decreased between 1995 and 2001. Thus, even though we cannot compare their size, the data indicate that the small private enterprise sector is a much more dynamic part of the Polish economy than it is in Russia, as Kornai contends.

The empirical evidence presented in Tables 5 and 6 and other authors' analysis of the new firm sector shows that these new firms are also the key to growing the aggregate economy, to creating an economic middle class and to maintaining a relatively equitable income distribution. We also think this is an important part of the answer to the question of why the income distributions in these two countries had diverged so dramatically during the 1990's. 


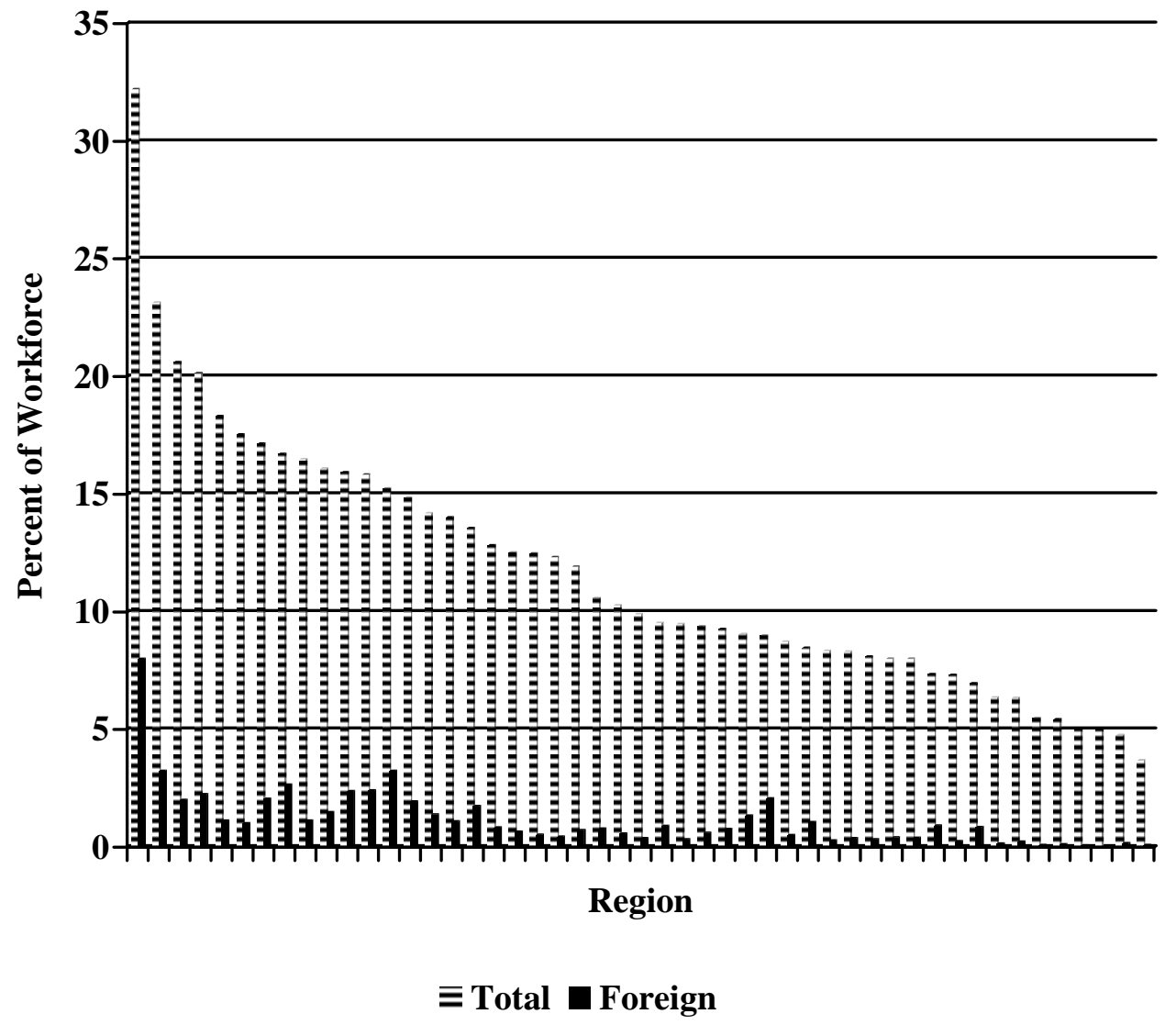

Fig. 1: Distribution of Proportion of all De Novo and Foreign Jobs in Poland, by Region 


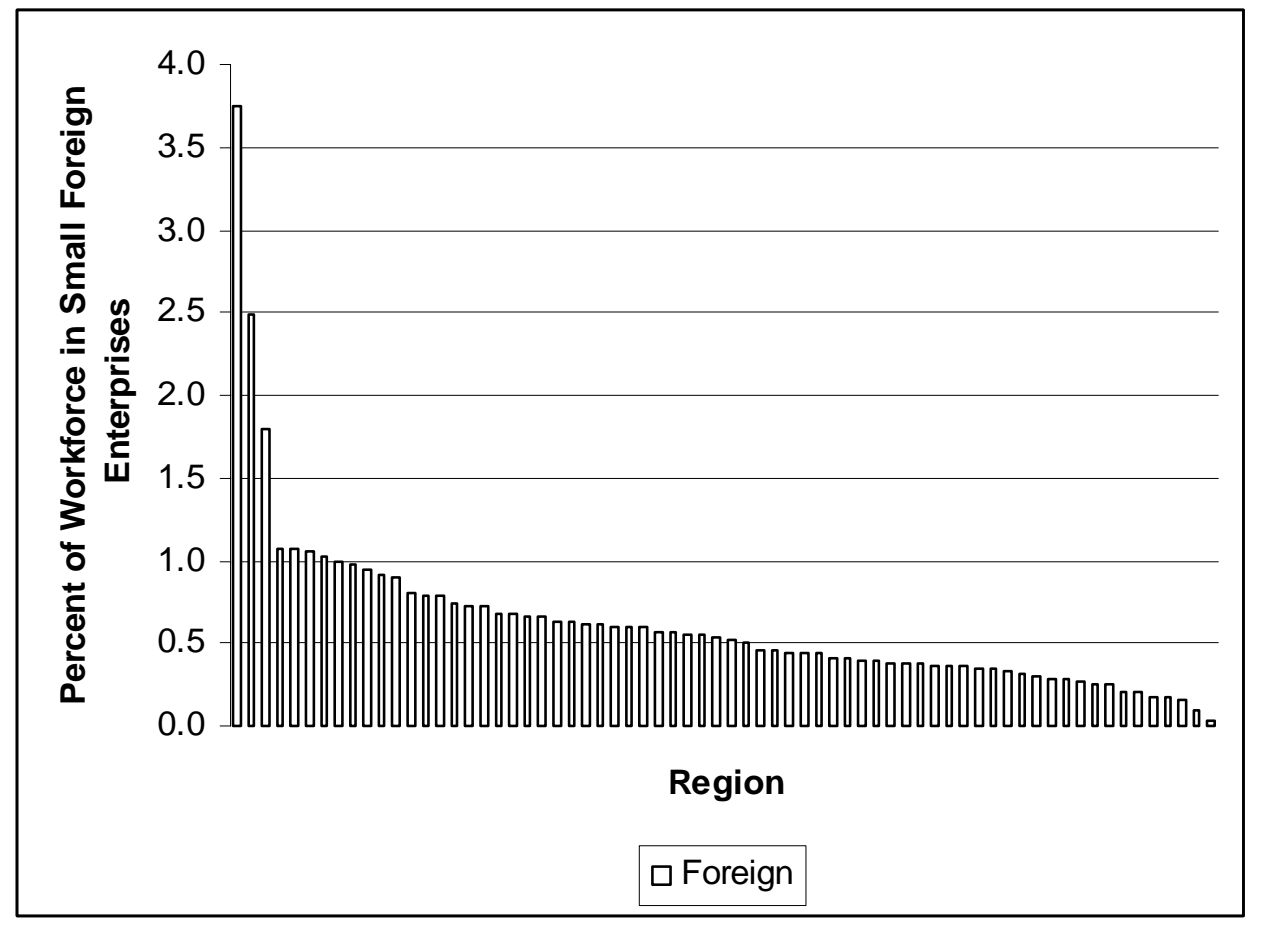

Fig. 2: Distribution ofWorkforce in Small Foreign Enterprises in Russian Region, 2001 


\begin{tabular}{|c|c|c|}
\hline Variable & 1993 & 1998 \\
\hline \multicolumn{3}{|c|}{$1^{\text {st }}$ Quintile Income Shares } \\
\hline Regional Mean & $7.94 \%$ & $8.06 \%$ \\
\hline Regional Median & $7.86 \%$ & $7.80 \%$ \\
\hline Regional St. Deviation & $1.08 \%$ & $1.50 \%$ \\
\hline Regional Minimum & $5.31 \%$ & $5.85 \%$ \\
\hline Regional Maximum & $10.38 \%$ & $14.68 \%$ \\
\hline \multicolumn{3}{|c|}{$1^{\text {st }}$ and $2^{\text {nd }}$ Quintile Income Shares } \\
\hline Regional Mean & $21.68 \%$ & $21.90 \%$ \\
\hline Regional Median & $21.36 \%$ & $21.82 \%$ \\
\hline Regional St. Deviation & $2.55 \%$ & $2.99 \%$ \\
\hline Regional Minimum & $15.65 \%$ & $17.11 \%$ \\
\hline Regional Maximum & $28.80 \%$ & $27.80 \%$ \\
\hline \multicolumn{3}{|l|}{ Sample Sizes } \\
\hline National & 4569 & 4151 \\
\hline Regional Mean & 95.2 & 86.5 \\
\hline Regional Median & 81 & 73.5 \\
\hline Regional Minimum & 22 & 21 \\
\hline Regional Maximum & 542 & 428 \\
\hline
\end{tabular}

Notes

(i) The Warsaw region is omitted from all statistics. 


\begin{tabular}{|c|c|c|c|}
\hline Variable & $1990^{\mathrm{a}}$ & 1993 & 1997 \\
\hline \multicolumn{4}{|c|}{ Firms/Thousand Population } \\
\hline Mean & 0.32 & & 1.92 \\
\hline Median & 0.30 & & 1.69 \\
\hline St. Deviation & 0.13 & & 0.79 \\
\hline Minimum & 0.13 & & 0.79 \\
\hline Maximum & 0.73 & & 4.42 \\
\hline \multicolumn{4}{|c|}{ New Employment/Workforce } \\
\hline Mean & 0.012 & 0.046 & 0.11 \\
\hline Median & 0.011 & 0.041 & 0.097 \\
\hline St. Deviation & 0.0062 & 0.020 & 0.047 \\
\hline Minimum & 0.0036 & 0.016 & 0.036 \\
\hline Maximum & 0.035 & 0.10 & 0.23 \\
\hline \multicolumn{4}{|c|}{$\Delta$ New Employment/Workforce, 1993-97 } \\
\hline Mean & & & 0.067 \\
\hline Median & & & 0.058 \\
\hline St. Deviation & & & 0.030 \\
\hline Minimum & & & 0.020 \\
\hline Maximum & & & 0.154 \\
\hline
\end{tabular}

\section{Notes}

(i) Entries for 1990 refer to firms with six to one hundred employees. 


\begin{tabular}{|c|c|c|}
\hline Variable & 1995 & 2001 \\
\hline \multicolumn{3}{|l|}{$1^{\text {st }}$ Quintile Income Shares } \\
\hline National Mean (full sample) & $7.61 \%$ & $7.09 \%$ \\
\hline Regional Mean (analyzed sub-sample) & $7.66 \%$ & $7.15 \%$ \\
\hline Regional Median & $8.00 \%$ & $7.25 \%$ \\
\hline Regional St. Deviation & $1.33 \%$ & $0.85 \%$ \\
\hline Regional Minimum & $4.70 \%$ & $4.70 \%$ \\
\hline Regional Maximum & $10.1 \%$ & $8.5 \%$ \\
\hline \multicolumn{3}{|l|}{$1^{\text {st }}$ and $2^{\text {nd }}$ Quintile Income Shares } \\
\hline National (full sample) & $20.0 \%$ & $19.0 \%$ \\
\hline Regional Mean (analyzed sub-sample) & $20.1 \%$ & $19.1 \%$ \\
\hline Regional Median & $20.9 \%$ & $19.4 \%$ \\
\hline Regional St. Deviation & $2.68 \%$ & $1.74 \%$ \\
\hline Regional Minimum & $13.9 \%$ & $13.9 \%$ \\
\hline Regional Maximum & $24.8 \%$ & $21.8 \%$ \\
\hline \multicolumn{3}{|l|}{ Sample Sizes (number of regions) } \\
\hline National (full sample) & 75 & 77 \\
\hline Regional (analyzed sample) & 66 & 66 \\
\hline Actual number of regions & 89 & 89 \\
\hline
\end{tabular}

Notes

(i) Moscow and St. Petersburg cities are omitted from all statistics. 


\begin{tabular}{|c|l|l|}
\hline \multicolumn{2}{|l|}{ Table 4: Description of Russia's Small Enterprises } \\
\hline Variable & 1996 & 2001 \\
\hline Firms/Population (1000) & & \\
\hline Mean & 3.84 & 2.34 \\
\hline Median & 3.76 & 2.18 \\
\hline St. Deviation & 1.41 & 1.02 \\
\hline Minimum & 1.71 & 1.09 \\
\hline Maximum & 9.40 & 5.98 \\
\hline Small Employment/Workforce & 1995 & 2001 \\
\hline Mean & 0.128 & 0.074 \\
\hline Median & 0.125 & 0.071 \\
\hline St. Deviation & 0.024 & 0.025 \\
\hline Minimum & 0.078 & 0.024 \\
\hline Maximum & 0.195 & 0.140 \\
\hline$\Delta$ Employment share, 1995-2001 & & -0.055 \\
\hline Mean & & -0.055 \\
\hline Median & & 0.030 \\
\hline St. Deviation & & -0.148 \\
\hline Minimum & & \\
\hline Maximum & & \\
\hline
\end{tabular}




\begin{tabular}{|c|c|c|c|}
\hline $\begin{array}{l}\text { Measure of small } \\
\text { enterprise development }\end{array}$ & $\begin{array}{l}\text { Employment } \\
\text { share of } \\
\text { workforce, } 1997\end{array}$ & $\begin{array}{l}\text { New enterprises } \\
\text { per capita, } 1997\end{array}$ & $\begin{array}{l}\Delta \text { Employment } \\
\text { share, } 1993-97\end{array}$ \\
\hline \multicolumn{4}{|c|}{$\begin{array}{l}\text { Panel A- Second Stage 2SLS Estimates Dependent Variable is Share of Income } \\
\text { Going to Bottom 40-percent }\end{array}$} \\
\hline $\begin{array}{l}\text { Small enterprise } \\
\text { development, } \\
\text { (instrumented) }\end{array}$ & $\begin{array}{l}30.6^{*} \\
(10.7) \\
\text { QS: } 1.44\end{array}$ & $\begin{array}{l}2.00^{*} \\
(0.79) \\
\text { QS: } 1.58\end{array}$ & $\begin{array}{l}57.3 * \\
(24.6) \\
\text { QS: } 1.72 \\
\end{array}$ \\
\hline Log population, 1998 & $\begin{array}{l}-1.01 * \\
(0.45)\end{array}$ & $\begin{array}{l}-1.14^{*} \\
(0.54)\end{array}$ & $\begin{array}{l}-1.32 * \\
(0.58)\end{array}$ \\
\hline Education, 1998 & $\begin{array}{l}-1.35^{* *} \\
(0.77)\end{array}$ & $\begin{array}{l}-1.46^{* *} \\
(0.85)\end{array}$ & $\begin{array}{l}-1.36^{* *} \\
(0.80)\end{array}$ \\
\hline Income Share - 1993 & $\begin{array}{l}-1.50 * \\
(0.22)\end{array}$ & $\begin{array}{l}-1.50^{*} \\
(0.21)\end{array}$ & $\begin{array}{l}-1.50^{*} \\
(0.23)\end{array}$ \\
\hline Centered $\mathrm{R}^{2}$ & 0.64 & 0.64 & 0.63 \\
\hline \multicolumn{4}{|c|}{ Panel B-Over-identification Tests For 2SLS Estimates: t-statistics } \\
\hline $\begin{array}{l}\text { Employment in private } \\
\text { firms in } 1990 \text { per } 1000 \\
\text { workforce (p-value) }\end{array}$ & $\begin{array}{l}-0.62 \\
(0.54)\end{array}$ & & $\begin{array}{l}-0.09 \\
(0.93)\end{array}$ \\
\hline $\begin{array}{l}1990 \text { private } \\
\text { employment per } 1000 \\
\text { population (p-value) }\end{array}$ & & $\begin{array}{l}-0.42 \\
(0.68)\end{array}$ & \\
\hline $\begin{array}{l}\text { Employment in state- } \\
\text { owned firms, } 1990 \\
\text { (p-value) }\end{array}$ & $\begin{array}{l}0.01 \\
(0.99)\end{array}$ & $\begin{array}{l}0.09 \\
(0.93)\end{array}$ & $\begin{array}{l}0.34 \\
(0.74)\end{array}$ \\
\hline $\begin{array}{l}\text { Employment in firms } \\
\text { privatized } 1990-93 \text { per } \\
1000 \text { workforce } \\
\text { (p-value) }\end{array}$ & $\begin{array}{l}0.76 \\
(0.45)\end{array}$ & $\begin{array}{l}0.50 \\
(0.62)\end{array}$ & $\begin{array}{l}0.49 \\
(0.63)\end{array}$ \\
\hline $\begin{array}{l}\text { J-test for joint exclusion } \\
\text { of privatization variables } \\
\text { (p-value) }\end{array}$ & $\begin{array}{l}1.50 \\
(0.47)\end{array}$ & $\begin{array}{l}1.83 \\
(0.40)\end{array}$ & $\begin{array}{l}1.60 \\
(0.45)\end{array}$ \\
\hline
\end{tabular}




\section{Table 5: Cont.}

Panel C-OLS Estimates of the Second Stage

\begin{tabular}{|c|c|c|c|}
\hline $\begin{array}{l}\text { Small enterprise } \\
\text { development, } 1998\end{array}$ & $\begin{array}{l}22.2^{*} \\
(10.21) \\
\text { QS: } 1.25\end{array}$ & $\begin{array}{l}1.27 * \\
(0.58) \\
\text { QS: } 2.15\end{array}$ & $\begin{array}{l}34.6^{*} \\
(15.22 \\
\text { QS: } 1.3 \\
\end{array}$ \\
\hline Log population, 1998 & $\begin{array}{l}-0.72^{*} \\
(0.76)\end{array}$ & $\begin{array}{l}-0.71 * \\
(0.75)\end{array}$ & $\begin{array}{l}-0.78 * \\
(0.76)\end{array}$ \\
\hline Education & $\begin{array}{l}-1.17 \\
(0.72)\end{array}$ & $\begin{array}{l}-1.18^{*} \\
(0.72)\end{array}$ & $\begin{array}{l}-1.09 \\
(0.70)\end{array}$ \\
\hline Share - 1993 & $\begin{array}{l}-1.51^{*} \\
(0.18)\end{array}$ & $\begin{array}{l}-1.51^{*} \\
(0.18)\end{array}$ & $\begin{array}{l}-1.51^{*} \\
(0.18)\end{array}$ \\
\hline Centered $\mathrm{R}^{2}$ & 0.62 & 0.62 & 0.62 \\
\hline
\end{tabular}

Panel D- First Stage Reduced Form OLS Regression

Dependent variables is small enterprise development, 2001

\begin{tabular}{|c|c|c|c|}
\hline $\begin{array}{l}\text { Privatization variables } \\
\text { (excluded instruments) } \\
\text { Employment in private } \\
\text { firms in } 1990 \text { per } 1000 \\
\text { workforce }\end{array}$ & $\begin{array}{l}3.64 * \\
(0.75)\end{array}$ & & $\begin{array}{l}1.56^{*} \\
(0.58)\end{array}$ \\
\hline per 1000 population & & $\begin{array}{l}2.76^{*} \\
(0.70)\end{array}$ & \\
\hline $\begin{array}{l}\text { Employment in state- } \\
\text { owned firms, } 1990\end{array}$ & $\begin{array}{l}-0.16^{* *} \\
(0.09)\end{array}$ & $\begin{array}{l}-2.98 * * \\
(1.65)\end{array}$ & $\begin{array}{l}-0.14 * \\
(0.07)\end{array}$ \\
\hline $\begin{array}{l}\text { Employment in firms } \\
\text { privatized } 1990-93 \text { per } \\
1000 \text { workforce }\end{array}$ & $\begin{array}{l}0.51 * * \\
(0.26)\end{array}$ & $\begin{array}{l}10.76^{*} \\
(4.94)\end{array}$ & $\begin{array}{l}0.38 * * \\
(0.20)\end{array}$ \\
\hline Log population, 1998 & $\begin{array}{l}0.05^{*} \\
(0.01)\end{array}$ & $\begin{array}{l}0.91 * \\
(0.27)\end{array}$ & $\begin{array}{l}0.04 * \\
(0.01)\end{array}$ \\
\hline Education, 1998 & $\begin{array}{l}0.008 \\
(0.008)\end{array}$ & $\begin{array}{l}0.14 \\
(0.15)\end{array}$ & $\begin{array}{l}0.005 \\
(0.006)\end{array}$ \\
\hline
\end{tabular}




\begin{tabular}{|l|l|l|l|}
\hline Income Share - 1993 & $\begin{array}{l}-0.001 \\
(0.002)\end{array}$ & $\begin{array}{l}-0.02 \\
(0.04)\end{array}$ & $\begin{array}{l}-0.001 \\
(0.002)\end{array}$ \\
\hline $\begin{array}{l}\text { F-statistic for excluded } \\
\text { instruments }\end{array}$ & 14.7 & 10.5 & 7.25 \\
\hline p-value of F-statistic & 0.000 & 0.000 & 0.001 \\
\hline $\begin{array}{l}\text { Partial } \mathrm{R}^{2} \text { of excluded } \\
\text { instruments }\end{array}$ & 0.52 & 0.435 & 0.35 \\
\hline
\end{tabular}

Notes

(i) Point estimates for regression coefficients and and standard errors (in parentheses) are reported.

(ii) The symbols $*$ and $* *$ denote significance at the 5-percent and 10-percent levels, respectively.

(iii) Standard errors in the second stage have a small sample correction; first and second stage standard errors are corrected for heteroskedasticity.

(iv) QS denotes quantitative significance, which is the impact of a one-standard deviation difference in small enterprise development (using the actual sample) on income distribution.

(v) Small private firms in 1990 have fewer than 100 employees. 


\begin{tabular}{|c|c|c|c|}
\hline \multicolumn{4}{|c|}{$\begin{array}{l}\text { Table } 6 \text { - Income Distribution and Small Enterprises } \\
\text { Russia Late Transition }\end{array}$} \\
\hline $\begin{array}{l}\text { Measure of small } \\
\text { enterprise development }\end{array}$ & $\begin{array}{l}\text { Employment } \\
\text { share of } \\
\text { workforce, } 2001\end{array}$ & $\begin{array}{l}\text { New enterprises } \\
\text { per capita, } 2001\end{array}$ & $\begin{array}{l}\Delta \text { Employment } \\
\text { share, 1995- } \\
2001\end{array}$ \\
\hline \multicolumn{4}{|c|}{ Panel A- Second Stage 2SLS Estimates } \\
\hline $\begin{array}{l}\text { Small enterprise } \\
\text { development } \\
\text { (instrumented) }\end{array}$ & $\begin{array}{l}38.9^{*} \\
(10.5) \\
\text { QS: } 0.98\end{array}$ & $\begin{array}{l}1.46^{*} \\
(0.59) \\
\text { QS: } 1.49 \\
\end{array}$ & $\begin{array}{l}76.5^{* *} \\
(38.4) \\
\text { QS: } 2.30 \\
\end{array}$ \\
\hline Log population -2001 & $\begin{array}{l}-0.82 * \\
(0.26)\end{array}$ & $\begin{array}{l}-0.85^{*} \\
(0.39)\end{array}$ & $\begin{array}{l}-2.29 * \\
(0.76)\end{array}$ \\
\hline Education-1994 & $\begin{array}{l}-0.19 * \\
(0.092)\end{array}$ & $\begin{array}{l}-0.47^{*} \\
(0.20)\end{array}$ & $\begin{array}{l}-0.16 \\
(0.16)\end{array}$ \\
\hline Income share-1995 & $\begin{array}{l}-0.79 * \\
(0.081)\end{array}$ & $\begin{array}{l}-0.80^{*} \\
(0.100)\end{array}$ & $\begin{array}{l}-0.98^{*} \\
(0.17)\end{array}$ \\
\hline Centered $\mathrm{R}^{2}$ & 0.69 & 0.44 & 0.16 \\
\hline \multicolumn{4}{|c|}{ Panel B-Over-identification Tests for 2SLS Estimates: t-statistics } \\
\hline $\begin{array}{l}\text { Large privatization, } 1993 \\
\text { (p-value) }\end{array}$ & $\begin{array}{l}0.08 \\
(0.94)\end{array}$ & $\begin{array}{l}0.60 \\
(0.55)\end{array}$ & $\begin{array}{l}0.90 \\
(0.37)\end{array}$ \\
\hline $\begin{array}{l}\text { Small privatization, } 1993 \\
\text { (p-value) }\end{array}$ & $\begin{array}{l}-0.08 \\
(0.94)\end{array}$ & $\begin{array}{l}-0.48 \\
(0.63)\end{array}$ & $\begin{array}{l}-0.41 \\
(0.68)\end{array}$ \\
\hline $\begin{array}{l}\text { J-test for joint exclusion } \\
\text { of privatization variables } \\
\text { (p-value) }\end{array}$ & $\begin{array}{l}0.006 \\
(0.94)\end{array}$ & $\begin{array}{l}0.354 \\
(0.55)\end{array}$ & $\begin{array}{l}0.64 \\
(0.42)\end{array}$ \\
\hline
\end{tabular}




\section{Table 6: Cont.}

Panel C-OLS Estimates of the Second Stage

\begin{tabular}{|c|c|c|c|}
\hline $\begin{array}{l}\text { Small enterprise } \\
\text { development, } 2001\end{array}$ & $\begin{array}{l}21.5^{*} \\
(6.67) \\
\text { QS: } 0.54\end{array}$ & $\begin{array}{l}0.20 \\
(0.26) \\
\text { QS: } 0.20\end{array}$ & $\begin{array}{l}7.94 \\
(7.29) \\
\text { QS: } 0.24\end{array}$ \\
\hline Log population, 2001 & $\begin{array}{l}-0.71 * \\
(0.27) \\
\end{array}$ & $\begin{array}{l}-0.60^{*} \\
(0.30)\end{array}$ & $\begin{array}{l}-0.74 \\
(0.37)\end{array}$ \\
\hline Education-1994 & $\begin{array}{l}-0.13^{*} \\
(0.077)\end{array}$ & $\begin{array}{l}-0.10 \\
(0.088)\end{array}$ & $\begin{array}{l}-0.058 \\
(0.082)\end{array}$ \\
\hline Income Share-1995 & $\begin{array}{l}-0.76^{*} \\
(0.076)\end{array}$ & $\begin{array}{l}-0.73 * \\
(0.075)\end{array}$ & $\begin{array}{l}-0.75^{*} \\
(0.075)\end{array}$ \\
\hline Centered $\mathrm{R}^{2}$ & 0.642 & 0.602 & 0.604 \\
\hline
\end{tabular}

Panel D- First Stage Reduced Form OLS Regression

Dependent variable is small enterprise development

\begin{tabular}{|c|c|c|c|}
\hline $\begin{array}{l}\text { Privatization variables } \\
\text { (excluded instruments): } \\
\text { Large privatization, } 1993 \\
\text { (firms per } 1000 \\
\text { population) }\end{array}$ & $\begin{array}{l}0.22 * \\
(0.066)\end{array}$ & $\begin{array}{l}3.61 \\
(2.24)\end{array}$ & $\begin{array}{l}0.054 \\
(0.085)\end{array}$ \\
\hline $\begin{array}{l}\text { Small privatization, } 1993 \\
\text { (firms per } 1000 \\
\text { population) }\end{array}$ & $\begin{array}{l}0.092 * \\
(0.022)\end{array}$ & $\begin{array}{l}2.88^{*} \\
(1.31)\end{array}$ & $\begin{array}{l}0.057^{*} \\
(0.028)\end{array}$ \\
\hline Log population, 2001 & $\begin{array}{l}0.0094 * \\
(0.0028)\end{array}$ & $\begin{array}{l}0.29 * * \\
(0.16)\end{array}$ & $\begin{array}{l}0.024 * \\
(0.0045)\end{array}$ \\
\hline Education, 1994 & $\begin{array}{l}0.0031 * \\
(0.0010)\end{array}$ & $\begin{array}{l}0.27^{*} \\
(0.060)\end{array}$ & $\begin{array}{l}0.0011 \\
(0.015)\end{array}$ \\
\hline Income share-1995 & $\begin{array}{l}0.0029 * \\
(0.00077)\end{array}$ & $\begin{array}{l}0.088 * \\
(0.031)\end{array}$ & $\begin{array}{l}0.0040 * \\
(0.0014)\end{array}$ \\
\hline $\begin{array}{l}\text { F-statistic for excluded } \\
\text { instruments }\end{array}$ & 28.8 & 4.86 & 3.11 \\
\hline
\end{tabular}




\begin{tabular}{|l|l|l|l|}
\hline p-value of F-statistic & 0.000 & 0.011 & 0.052 \\
\hline $\begin{array}{l}\text { Partial } \mathrm{R}^{2} \text { of excluded } \\
\text { instruments }\end{array}$ & 0.40 & 0.22 & 0.087 \\
\hline
\end{tabular}

Notes

(i) Point estimates for regression coefficients and standard errors (in parentheses) are reported.

(ii) The symbols * and ** denote significance at the 5-percent and 10-percent levels, respectively.

(iii) Standard errors in the second stage have a small sample correction; first and second stage standard errors are corrected for heteroskedasticity.

(iv) QS denotes quantitative significance, which is the impact of a one-standard deviation in small enterprise development (using the actual sample) on income distribution. 


\begin{tabular}{|c|c|c|c|}
\hline \multicolumn{4}{|c|}{$\begin{array}{l}\text { Table 7: Indirect Quantit } \\
\text { On Income Distribution }\end{array}$} \\
\hline \multicolumn{4}{|l|}{ Panel A-Poland } \\
\hline $\begin{array}{l}\text { Measure of small } \\
\text { enterprise development }\end{array}$ & $\begin{array}{l}\text { Employment } \\
\text { share of } \\
\text { workforce, } 1997\end{array}$ & $\begin{array}{l}\text { New } \\
\text { enterprises per } \\
\text { capita, } 1997\end{array}$ & $\begin{array}{l}\Delta \text { Employment } \\
\text { share, 1993- } \\
1997\end{array}$ \\
\hline Early Privatization & & & \\
\hline $\begin{array}{l}\text { Employment in private } \\
\text { firms in } 1990\end{array}$ & 0.687 & & 0.551 \\
\hline Private firms in 1990 & & 0.716 & \\
\hline $\begin{array}{l}\text { Employment in firms } \\
\text { privatized 1990-93 }\end{array}$ & 0.339 & 0.467 & 0.472 \\
\hline \multicolumn{4}{|l|}{ Panel B-Russia } \\
\hline $\begin{array}{l}\text { Measure of small } \\
\text { enterprise development }\end{array}$ & $\begin{array}{l}\text { Employment } \\
\text { share of } \\
\text { workforce, } 2001\end{array}$ & $\begin{array}{l}\text { New } \\
\text { enterprises per } \\
\text { capita, } 2001\end{array}$ & $\begin{array}{l}\Delta \text { Employment } \\
\text { share, 1995- } \\
2001\end{array}$ \\
\hline \multicolumn{4}{|l|}{ Early Privatization: } \\
\hline $\begin{array}{l}\text { Large privatization, } \\
1993\end{array}$ & 0.31 & 0.19 & 0.15 \\
\hline $\begin{array}{l}\text { Small privatization, } \\
1993\end{array}$ & 0.41 & 0.48 & 0.50 \\
\hline
\end{tabular}

Notes

(i) Indirect quantitative significance is computed as a one-standard deviation increase in the early privatization variable times the impact of that early privatization variable on small enterprise formation times the impact of the small enterprise variable on income distribution. 


\section{References}

Acemoglu, Daron, Johnson, Simon, Robinson, James, 2001. The colonial origins of comparative development: an empirical investigation., American Economic Review 91(5), 1369-1401.

Aghion, Philippe, Caroli, Eva,Garcia-Peñalosa, Cecilia, 1999. Inequality and economic growth: the perspective of the new growth theories. Journal of Economic Literature 37(4), 1615-60.

Alexeev, Michael, 1999. The effect of privatization on wealth distribution in Russia." The Economics of Transition 7(2), 449-65.

Bartelsman, Eric J., Haltiwanger, John, Scarpetta, Stefano, 2004. Microeconomic evidence of creative destruction in industrial and developing countries.Discussion Paper 114/3. Tinbergen Institute.

Baum, Christopher, F., Schaffer, Mark, E.,Stillman, Steven, 2003. Instrumental variables and GMM: estimation and testing. The Stata Journal 3(1), 1-31.

Berkowitz, Daniel, DeJong, David, N., 2005. Entrepreneurship and post-socialist growth. Oxford Bulletin of Economics and Statistics 67(1), 25-46.

Berkowitz, Daniel, Holland, Jonathan, 2001. Does privatization enhance or deter small enterprise formation? Economics Letters 74, 53-60.

Berkowitz, Daniel, Li, Wei , 2000. Tax rights in transition economies: a tragedy of the commons? Journal of Public Economics 76, 369-397.

Bilsen, Valentijn, Konings, Jozef, 1998. Job creation, job destruction and employment growth in newly established firms in transition countries: survey evidence from Romania, Bulgaria and Hungary. Journal of Comparative Economics 26(3), 429-445.

Black, B., Kraakman, R., Tarassova, A., 2000. Russian privatization and corporate governance: what went wrong? Stanford Law Review 52, 1731-1810.

Boycko, M., Shleifer, Andrei, Vishny, Robert, 1995. Privatizing Russia. MIT Press, Cambridge, MA. 
Chao, John, Swanson, Norman, 2003. Alternative approximations of the bias and MSE of the IV estimator under weak identification with an application to bias correction. mimeo, University of Maryland.

De Loecker, Jan, Konings, Jozef, 2006. Creative destruction and productivity growth: evidence from Slovenia. European Journal of Political Economy Forthcoming.

European Bank for Reconstruction and Development (EBRD), 2003. Transition report 2003: integration and regional cooperation. EBRD, London.

Forbes, Kristin, 2000. A reassessment of the relationship between inequality and growth. American Economic Review. 90(4), 869-87.

Frye, Timothy, Shleifer, Andrei, 1997. The invisible hand and the grabbing hand. American Economic Review 87, 354-358.

Cichomski, Bogdan, Morawski, Pawel, 2002. Polish General Social Surveys: machine readable data file 1992-1999. Institute for Social Studies, University of Warsaw, Warsaw, PL.

Gabszewicz , J., Jaskold, Thisse, J. -F., 1980, Entry (and exit) in a differential industry. Journal of Economic Theory 22, 327-338.

Goskomstat Rossii. 1994 and 1996. Rossiskiy Statisticheskiy Yezhegodnik. Goskomstat Rossii, Moskva.

Goskomstat Rossii, 2001 and 2002. Regiony Rossii, Goskomstat Rossii, Moskva

Hahn, Jinyong, Hausman, Jerry, 2002. Notes on bias in estimators for simultaneous equation models., Economic Letters 75, 237-41.

Hansen, Lars, Peter, 1982. Large sample properties of generalized method of moment estimators. Econometrica 50, 1029-1054.

Hellman, Joel, S., 1998.Winners take all: the politics of partial reforms in post-communist transitions. World Politics 50(2), 203-234. 
Hellman, Joel, S.,Jones, Geraint, Kaufman, Daniel, 2000. Seize the state, seize the day: state capture, corruption and influence in transition.” Policy Research Working Paper 2444. World Bank, Washington, DC.

Jackson, John, E., 2003. A computational political economy model of transition. In: Jan Fidrmuc and Nauro Campos (eds.), Political Economy of Transition and Development: Institutions, Politics, and Policies. Klewer Academic Publishers, Boston/Dordrecht/London, pp. 117-137.

Jackson, John, E., Klich, Jacek, Poznańska, Krystyna, 1999. Firm creation and economic transitions., Journal of Business Venturing 14(5/6), 427-450.

Jackson, John, E., Klich, Jacek, Poznańska, Krystyna, 2005. The Political Economy of Poland's Transition: New Firms and Reform Governments. Cambridge University Press, Cambridge, England/New York, NY.

Jackson, John, E., Marcinkowski, Aleksander S., 1999. The entrepreneurial attitudes of Poles. In: Hauser, Ewa, Wasilewski, Jacek (eds.) Lessons in Democracy. University of Rochester Press, Rochester, NY and Jagiellonian University Press, Kraków, PL, pp. 171-200.

Jackson, John, E.,Rodkey, Gretchen R., 1994. The attitudinal climate for entrepreneurial activity. Public Opinion Quarterly 58(3), 358-380.

Johnson, Simon, McMillan, John, Woodruff, Christopher, 2002. Property rights, finance and entrepreneurship. American Economic Review 92, 1335-1356.

Jurjada, Štepán, Terrell, Katherine, 2001. What drives the speed of job reallocation during episodes of massive adjustment? Working Paper \#432. William Davidson Institute, Ann Arbor, MI, USA.

Karatnycky, Adrian, Motyl, Alexander, Schnetzer, Amanda, 2001. Nations in Transit. Freedom House, New York, NY.

Keane, Michael, Prassad, Enwar, 2002. Inequality, transfers and growth: new evidence from economic transition in Poland. Review of Economics and Statistics 84(2), 324-341. 
Klapper, Leora, Laeven, Luc, Rajan, Raghuram, 2004. Business environment and firm entry: evidence from international data." Working Paper 10380, NBER.

Kornai, János, 2000. Ten years after 'The Road to a Free Economy’: the author's self-evaluation. Paper prepared for the Annual Bank Conference on Development Economics. World Bank Washington, DC.

Luttmer, Erzo F.P., 2002. Measuring economic mobility and inequality: disentangling real events from noisy data," Available at http://www.nber.org/ luttmer/mobility.pdf. Harris School of Public Policy Studies, University of Chicago, Chicago, IL.

McMillan, John, 1995. Markets in transition. In: Kreps, David, M., Wallis, K.F. (eds), Advances in Economics and Econometrics. Cambridge University Press, Cambridge, chapter 6.

McMillan, John, Woodruff, Christopher, 2002. The central role of entrepreneurs in transition economies. Journal of Economics Perspectives 16, 153-170.

Shaked, Avner, Sutton, John, 1982. Relaxing price competition through product differentiation. Review of Economic Studies 49(1), 3-13.

Shleifer, Andrei, Vishny, Robert, 1993. Corruption.. Quarterly Journal of Economics 58(3), 599-617.

Tichit, Ariane, 2006. The optimal speed of transition revisited. European Journal of Political Economy Forthcoming.

Transparency International, 1996. TI Corruption Perception Index 1996. Available at http://www.transparency.org/cpi/1996/cpi1996.pdf. Berlin.

UNICEF. 2001. A Decade of Transition. Regional Monitoring Project No. 8. UNICEF Innocenti Research Centre. Florence, Italy.

United Nations, 2005. Human Development Report 2005. United Nations Development Program, New York.

White, Halbert, 1980. A heteroskedasticity-consistent covariance matrix estimator and direct test for heteroskedasticity. Econometrica 48(4), 817-838. 
World Bank. 2000. Making Transition Work for Everyone: Poverty and Inequality in Europe and Central Asia. Washington, DC. 


\section{Endnotes}

${ }^{1}$ See Keane and Prassad (2002) for an overview of income distribution dynamics in Poland during the 1990s.

${ }^{2}$ See Luttmer (2002) for a comparison of income distribution in Poland and Russia.

${ }^{3}$ An additional explanation for the elimination of monopoly rents in Poland and their persistence in Russia is that Poland became more open to foreign trade. We calculate the share of trade in GDP during years seven through ten of reform (1996-99 in Poland and 1998-2001 in Russia). The share in Poland is $42.2 \%$, which is less than the $54.0 \%$ share in Russia. Furthermore, the share of trade with non-transition countries in Poland is $35.2 \%$, which is less than the $37.4 \%$ share in Russia (see EBRD, 2003, p. 178 and p.186).

${ }^{4}$ There is also a 1995 study that is not included in our analysis.

${ }^{5}$ Some registrations are solely for tax purposes and the agency responsible for these data do not record exits, both of which lead to overstatements of the size of this sector. Including these data for firms with five or fewer employees with our data on those with over five employees would imply more job creation than job loss during the transition, which is inconsistent with the ten percent unemployment rate in 1997.

${ }^{6}$ The regional privatization combined voucher and cash privatization of large and medium sized companies. In an effort to avoid problems associated with over-identification, we do not include early regional privatization.

${ }^{7}$ For the equation with new firms per capita we denominate the employment in small firms by population. 
${ }^{8}$ As with all conventional statistical tests, not rejecting the null hypothesis does not mean we can accept it. On the other hand, the higher the probability of getting our statistical results by chance under the null, the more likely the null is to be correct.

${ }^{9}$ The privatized employment in 1993 and the state-owned employment in 1990 are denominated by the non-farm workforce as we are using these variables to measure the concentration of industrial and commercial activity in these firms. For the small private and de novo sector variables we are trying to assess the level of participation of the entire workforce in these enterprises.

${ }^{10}$ Hahn and Hausman (2002) and Chao and Swannson (2003) show that over-identification can create OLS bias when two stage least squares (2SLS) is used. Simulation results in Chao and Swannson (Table 2) show that one way to offset this bias is to use limited information maximum likelihood (LIML). Because the difference between our 2SLS and LIML estimates are negligible, we report only the 2SLS results (LIML results are available upon request).

${ }^{11}$ A table including Moscow and St. Petersburg similar to table 6 is available from the authors on request.

${ }^{12}$ A table of the statistical results is available from the authors on request. 